\title{
Effect of Fertilizer Management Practices on Grain Yields, Concentrations of Micronutrient Cations and Phytic Acid in Rice and Wheat Grains under a Long Term Fertility Trial
}

\author{
S. P. Pachauri ${ }^{1}$, P. C. Srivastava ${ }^{1}$, Deepa Rawat ${ }^{1}$, B. Mathpal ${ }^{2}$, \\ S. C. Sankhyadhar ${ }^{2}$, P. C. Pandey $^{3}$ and A. K. Shukla ${ }^{4}$ \\ ${ }^{1}$ Department of Soil Science, ${ }^{2}$ Department of Plant Physiology, \\ ${ }^{3}$ Department of Agronomy, G.B. Pant University of Agriculture \& Technology, Pantnagar- \\ 263145, Uttarakhand, India \\ ${ }^{4}$ Indian Institute of Soil Science, Nabibagh, Bhopal-462038, Madhya Pradesh, India \\ *Corresponding author
}

Keywords

Fertilizer management, Micronutrient cations, Phytic acid, Rice and wheat

Article Info

Accepted:

15 January 2021

Available Online:

10 February 2021
The effects of fertilizer management practices on rice and wheat grain yields, concentrations of micronutrient cations and phytic acid were evaluated in a long term were analyzed. The highest grain yield of rice was recorded under treatment T9 $\left(\mathrm{N}_{120} \mathrm{P}_{40} \mathrm{~K}_{40}+\mathrm{Znf}+\mathrm{FYM}\right)$ while that of wheat under treatment $\mathrm{T}_{11}$ $\left(\mathrm{N}_{180} \mathrm{P}_{80} \mathrm{~K}_{40}+\mathrm{Znf}+\mathrm{FYM}\right)$. Application of T6 $\left(\mathrm{N}_{120} \mathrm{P}_{60} \mathrm{~K}_{40}\right)$, T7 $\left(\mathrm{N}_{120} \mathrm{P}_{40} \mathrm{~K}_{40}+\mathrm{Znf}\right)$, T8 $\left(\mathrm{N}_{120} \mathrm{P}_{40} \mathrm{~K}_{40}+\mathrm{FYM} @ 5 \mathrm{t} / \mathrm{ha}\right), \quad \mathrm{T} 9 \quad\left(\mathrm{~N}_{120} \mathrm{P}_{40} \mathrm{~K}_{40}+\mathrm{Znf}+\mathrm{FYM} @ \mathrm{t} / \mathrm{ha}\right), \mathrm{T} 10$ $\left(\mathrm{N}_{180} \mathrm{P}_{80}+\mathrm{Znf}\right)$ and T13 $\left(\mathrm{N}_{180} \mathrm{P}_{80} \mathrm{~K}_{40}+\mathrm{Znf}\right)$ significantly increased in $\mathrm{Zn}$ content of dehusked rice grains by $34.8,57.2,38.4,49.0,44.0$ and 60.1 percent over the control, respectively. Application of T5 $\left(\mathrm{N}_{120} \mathrm{~K}_{40}\right), \mathrm{T} 7\left(\mathrm{~N}_{120} \mathrm{P}_{40} \mathrm{~K}_{40}+\mathrm{Znf}\right), \mathrm{T} 10$ $\left(\mathrm{N}_{180} \mathrm{P}_{80}+\mathrm{Znf}\right)$ and T13 $\left(\mathrm{N}_{180} \mathrm{P}_{80} \mathrm{~K}_{40}+\mathrm{Znf}\right)$ increased in Fe content of dehusked rice grains significantly by $114.6,89.9,135.1$ and 65.9 percent over the control, respectively. In wheat crop, application of T2 $\left(\mathrm{N}_{120}\right)$, T3 $\left(\mathrm{N}_{120} \mathrm{P}_{40}\right)$, T5 $\left(\mathrm{N}_{120} \mathrm{~K}_{40}\right)$, T6 $\left(\mathrm{N}_{120} \mathrm{P}_{60} \mathrm{~K}_{40}\right), \quad \mathrm{T} 10 \quad\left(\mathrm{~N}_{180} \mathrm{P}_{80}+\mathrm{Znf}\right), \quad \mathrm{T} 11 \quad\left(\mathrm{~N}_{180} \mathrm{P}_{80} \mathrm{~K}_{40}+\mathrm{Znf}+\mathrm{FYM}\right), \quad \mathrm{T} 12$ $\left(\mathrm{N}_{150} \mathrm{P}_{40} \mathrm{~K}_{40}\right)$ and $\mathrm{T} 13\left(\mathrm{~N}_{180} \mathrm{P}_{80} \mathrm{~K}_{40}+\mathrm{Znf}\right)$ increased in $\mathrm{Zn}$ content of wheat grains significantly by $30.3,19.1,20.5,29.5,35.1,18.3,28.7$ and 40.3 percent over the control, respectively. Application of T9 $\left(\mathrm{N}_{120} \mathrm{P}_{40} \mathrm{~K}_{40}+\mathrm{Znf}+\mathrm{FYM} @ 5 \mathrm{t} / \mathrm{ha}\right)$ and $\mathrm{T} 13$ $\left(\mathrm{N}_{180} \mathrm{P}_{80} \mathrm{~K}_{40}+\mathrm{Znf}\right)$ increased the content of phytic acid in the dehusked rice grains by 10.0 and 2.0 percent over the control, respectively while application of T3 $\left(\mathrm{N}_{120} \mathrm{P}_{40}\right)$ decreased phytic acid by 12.2 percent in comparison to control. In wheat crop, application of $\mathrm{T} 8\left(\mathrm{~N}_{120} \mathrm{P}_{40} \mathrm{~K}_{40}+\mathrm{FYM}\right)$ and $\mathrm{T} 12\left(\mathrm{~N}_{150} \mathrm{P}_{40} \mathrm{~K}_{40}\right)$ increased the content of phytic acid in the wheat grains by 1.9 and 2.5 percent, respectively and application of $\mathrm{T} 2\left(\mathrm{~N}_{120}\right)$ and $\mathrm{T} 6\left(\mathrm{~N}_{120} \mathrm{P}_{60} \mathrm{~K}_{40}\right)$ decreased the content of phytic acid by 4.4 and 2.7 percent, respectively in comparison to control. 


\section{Introduction}

In Asian countries, the staple diet is mainly cereal based, the consumption of cereals raised on $\mathrm{Zn}$ deficient soils often leads to inadequate intake of $\mathrm{Zn}$ in young children and population. Low dietary $\mathrm{Zn}$ levels cause the growth impairment and poor immune functions finally exposing the population to diarrhoea and pneumonia (Volkmar and Bremer, 1998; Graham, 2008). Brain function and development in newborns has been linked to $\mathrm{Zn}$ deficiency (Benton, 2008). Zinc deficiency has been reported to account nearly 450,000 deaths in children below five years age (Black et al., 2008; Cakmak, 2010). Fertilizer management practices are likely to influence the level of micronutrients cations in cereal grains. The bioavailability of micronutrient cations present in the diet is influenced by the level of anti-nutrient factors present in the diet.

Phytic acid (myo-inositol 1,2,3,4,5,6hexakisphosphate) is a known anti-nutrient factor in the cereals because nearly $70 \%$ of total phosphorus in seeds is associated with phytic acid (Lott, 1984). Phytic acid strongly chelate micronutrients like $\mathrm{Zn}$ and $\mathrm{Fe}$ resulting in poor bioavailability of these minerals (Rhou and Erdman, 1995). In the present investigation, we attempted to study the effect of long-term fertilizer management practices under a long-term fertilizer management experiment of Department of Agronomy which was set-up in the year 1978 on the concentrations of micronutrient cations and also that of phytic acid in rice and wheat which form staple food for the majority of Indian population.

\section{Materials and Methods}

The initial soil properties of the experimental plot classified under the soil order Mollisol were, silt loam texture, $8.0 \mathrm{pH}, 0.12 \mathrm{dSm}^{-1}$
E.C., $21.0 \mathrm{~g}$ organic $\mathrm{C} \mathrm{kg}^{-1}$ soil, $0.1 \%$ total $\mathrm{N}$, $20.0 \mathrm{~kg}$ Olsen's $\mathrm{P} \mathrm{ha}^{-1}, 222 \mathrm{~kg}$ ammonium acetate extractable $\mathrm{K} \mathrm{ha}^{-1}$ and $0.80 \mathrm{mg}$ DTPA extractable $\mathrm{Zn} \mathrm{kg}^{-1}$ soil. Considering $1.24 \mathrm{mg}$ DTPA extractable $\mathrm{Zn} \mathrm{kg}^{-1}$ soil as the critical limit of $\mathrm{Zn}$ in mollisols for rice crop, the experimental soil was deficient in $\mathrm{Zn}$ (Srivastava and Gangwar, 1990). The details of treatments imposed in quadruplicate under randomized block design were: T1 Control; T2 $\mathrm{N}_{120} ; \mathrm{T} 3 \mathrm{~N}_{120} \mathrm{P}_{40} ; \mathrm{T} 4 \mathrm{P}_{40} \mathrm{~K}_{40} ; \mathrm{T} 5 \mathrm{~N}_{120} \mathrm{~K}_{40}$; T6 $\quad \mathrm{N}_{120} \mathrm{P}_{60} \mathrm{~K}_{40} ; \quad \mathrm{T} 7 \quad \mathrm{~N}_{120} \mathrm{P}_{40} \mathrm{~K}_{40}+\mathrm{Znf} ; \quad \mathrm{T} 8$ $\mathrm{N}_{120} \mathrm{P}_{40} \mathrm{~K}_{40}+\mathrm{FYM} @ 5 \quad \mathrm{t} / \mathrm{ha} ; \quad \mathrm{T} 9$ $\mathrm{N}_{120} \mathrm{P}_{40} \mathrm{~K}_{40}+\mathrm{Znf}+\mathrm{FYM} @ 5$ t/ha; $\quad \mathrm{T} 10$ $\mathrm{N}_{180} \mathrm{P}_{80}+\mathrm{Znf}$; T11 $\mathrm{N}_{180} \mathrm{P}_{80} \mathrm{~K}_{40}+\mathrm{Znf}+\mathrm{FYM} @ 5$ t/ha; T12 $\mathrm{N}_{150} \mathrm{P}_{40} \mathrm{~K}_{40} ;$ T13 $\mathrm{N}_{180} \mathrm{P}_{80} \mathrm{~K}_{40}+\mathrm{Znf}$; T14 $\mathrm{N}_{120} \mathrm{P}_{40} \mathrm{~K}_{40}$ (DAP). Among the treatments, $\mathrm{P}$ application as $\mathrm{kg}_{2} \mathrm{O}_{5} / \mathrm{ha}$ was done through DAP in T14 while in other relevant treatments it was through SSP. The treatment ( $\mathrm{Znf}$ ) implied application of foliar spray of $0.5 \%$ $\mathrm{ZnSO}_{4}$ solution neutralized by lime water. The gross plot size was $19.72 \mathrm{~m}^{2}(5.8 \mathrm{X} 3.4 \mathrm{~m})$ while the net plot size was $7.2 \mathrm{~m}^{2}(4.0 \mathrm{~m} \times 1.8 \mathrm{~m})$. Rice (cv. PD 4) and wheat (cv. UP 2565) were raised following the standard agronomic practices. The crop yields were recorded and expressed in $\mathrm{t} \mathrm{ha}^{-1}$..

Rice (dehusked) and wheat grains were digested in di-acid mixture $\left(\mathrm{HNO}_{3}: \mathrm{HClO}_{4}\right.$, $3: 1 \mathrm{v} / \mathrm{v})$ and analyzed for micronutrient cations using atomic absorption spectrophotometer (GBC AvantaM model). Phytic acid was estimated in grains using a method described by Harland and Oberleas (1977). The statistical analysis of data for all the parameters was carried out with analysis of variance.

The means were tested at $P>0.05$ using the STPR software designed at the Department of Mathematics, Statistics and Computer Science, CBSH, G.B. Pant University of Agriculture and Technology, Pantnagar, India. The significant differences among the 
treatments were calculated at $5 \%$ probability levels ( $\mathrm{p} \leq 0.05)$ (Snedecor and Cochran, 1967).

\section{Results and Discussion}

\section{Grain yields}

Among the treatments, the highest grain yield of rice $\left(6.29 \mathrm{t} \mathrm{ha}^{-1}\right)$ was recorded in the treatment $\mathrm{T} 9\left(\mathrm{~N}_{120} \mathrm{P}_{40} \mathrm{~K}_{40}+\mathrm{Znf}+\mathrm{FYM}\right)$ (Fig. 1) and the highest grain yield of wheat (5.36 $\mathrm{t} \mathrm{ha}^{-1}$ ) was recorded in the treatment $\mathrm{T}_{11}$ $\left(\mathrm{N}_{180} \mathrm{P}_{80} \mathrm{~K}_{40}+\mathrm{Znf}+\mathrm{FYM}\right)$ (Fig. 2). This indicated that the lack of balanced application of nutrients and no use of FYM under ricewheat rotation could threaten the sustainability of the cereal production. The response of $\mathrm{Zn}$ foliar spray in enhancing the grain yields of rice and wheat crops had been reported in Mollisols (Srivastava et al., 2013).

Micronutrient cations and phytic acid in rice (dehusked) grains

Among the treatments, application of $\mathrm{T} 6$ $\left(\mathrm{N}_{120} \mathrm{P}_{60} \mathrm{~K}_{40}\right), \quad \mathrm{T} 7 \quad\left(\mathrm{~N}_{120} \mathrm{P}_{40} \mathrm{~K}_{40}+\mathrm{Znf}\right), \quad \mathrm{T} 8$ $\left(\mathrm{N}_{120} \mathrm{P}_{40} \mathrm{~K}_{40}+\mathrm{FYM} @ 5\right.$ t/ha), $\quad$ T9 $\left(\mathrm{N}_{120} \mathrm{P}_{40} \mathrm{~K}_{40}+\mathrm{Znf}+\mathrm{FYM} @ 5\right.$ t/ha), T10 $\left(\mathrm{N}_{180} \mathrm{P}_{80}+\mathrm{Znf}\right)$ and $\mathrm{T} 13 \quad\left(\mathrm{~N}_{180} \mathrm{P}_{80} \mathrm{~K}_{40}+\mathrm{Znf}\right)$ increased in $\mathrm{Zn}$ content of dehusked rice grains significantly by $34.8,57.2,38.4,49.0$, 44.0 and 60.1 percent over the control, respectively (Table 1).

Interestingly, a comparison of $\mathrm{Zn}$ content in dehusked rice grain raised under T14 $\left(\mathrm{N}_{120} \mathrm{P}_{60} \mathrm{~K}_{40}\right.$, supplied through DAP) with that of control revealed that continuous use of DAP did not help in raising the content of $\mathrm{Zn}$ in dehusked rice grains. Gianquinto et al., (2000) also reported that applications of large amounts of fertilizer $\mathrm{P}$ to soils that are low in available $\mathrm{Zn}$ can depress tissue $\mathrm{Zn}$ concentration or may even induce $\mathrm{Zn}$ deficiency. Application of T5 $\left(\mathrm{N}_{120} \mathrm{~K}_{40}\right), \mathrm{T} 7$ $\left(\mathrm{N}_{120} \mathrm{P}_{40} \mathrm{~K}_{40}+\mathrm{Znf}\right), \mathrm{T} 10\left(\mathrm{~N}_{180} \mathrm{P}_{80}+\mathrm{Znf}\right)$ and T13 $\left(\mathrm{N}_{180} \mathrm{P}_{80} \mathrm{~K}_{40}+\mathrm{Znf}\right)$ increased in $\mathrm{Fe}$ content of dehusked rice grains significantly by 114.6 , 89.9, 135.1 and 65.9 percent over the control, respectively. Compared to wheat the dehusked rice grain is as such poor source of $\mathrm{Zn}$ and $\mathrm{Fe}$ minerals for human beings and foliar application of $\mathrm{Zn}$ appeared to be an effective strategy to improve dietary intake of these minerals in Asian countries. Davidsson et al., (1995) also demonstrated that iron fortification of foods was unlikely to affect zinc absorption.

They examined the effect of iron fortification of bread $(65 \mathrm{mg} / \mathrm{kg})$, weaning cereal $(500$ $\mathrm{mg} / \mathrm{kg}$ ) and infant formula (12 $\mathrm{mg} / \mathrm{L})$ in human adults with the use of stable isotopes and found no significant negative effect on zinc absorption was found compared with the same foods without iron fortification.

Application of $\mathrm{T} 7\left(\mathrm{~N}_{120} \mathrm{P}_{40} \mathrm{~K}_{40}+\mathrm{Znf}\right)$ increased in $\mathrm{Mn}$ content of dehusked rice grains significantly by 33.7 percent over the control while application of T2 $\left(\mathrm{N}_{120} \mathrm{P}_{40}\right), \quad \mathrm{T} 5$ $\left(\mathrm{N}_{120} \mathrm{~K}_{40}\right)$, and T8 $\left(\mathrm{N}_{120} \mathrm{P}_{40} \mathrm{~K}_{40}+\mathrm{FYM} @ 5 \mathrm{t} / \mathrm{ha}\right)$ brought a significant decrease in $\mathrm{Mn}$ content of dehusked rice grains in comparison to control indicating that missing application of phosphatic fertilizer could lead to lower $\mathrm{Mn}$ content in rice grains. The content of $\mathrm{Cu}$ in dehusked grains of rice was not significantly influenced by the imposed treatments.

The content of phytic acid in dehusked grains of rice was significantly influenced by treatments. Application of T9 $\left(\mathrm{N}_{120} \mathrm{P}_{40} \mathrm{~K}_{40}+\mathrm{Znf}+\mathrm{FYM} @ 5 \mathrm{t} / \mathrm{ha}\right)$ and $\mathrm{T} 13$ $\left(\mathrm{N}_{180} \mathrm{P}_{80} \mathrm{~K}_{40}+\mathrm{Znf}\right)$ increased the content of phytic acid in the dehusked grains by 10.0 and 2.0 percent over the control, respectively while application of $\mathrm{T} 3\left(\mathrm{~N}_{120} \mathrm{P}_{40}\right)$ brought a significant decrease of 12.2 per cent in the content of phytic acid in comparison to control. Higher content of phytic acid in dehusked rice grains could substancially reduce the bioavailability of both $\mathrm{Zn}$ and $\mathrm{Fe}$ in humans. 
Table.1 Effect of different treatments on concentration $\left(\mathrm{mg} \mathrm{kg}^{-1}\right)$ of micronutrient cations and phytic acid in dehusked rice (cv. PD4) grains.

\begin{tabular}{|c|c|c|c|c|c|}
\hline Treatments & Zn & Cu & Fe & Mn & Phytic acid \\
\hline T1 -Control & 8.6 & 1.4 & 5.3 & 17.1 & 3417 \\
\hline $\mathrm{T} 2-\mathrm{N}_{120}$ & 8.9 & 1.6 & 4.3 & 13.1 & 3237 \\
\hline $\mathrm{T} 3-\mathrm{N}_{120} \mathrm{P}_{40}$ & 10.6 & 1.4 & 6.1 & 16.0 & 3002 \\
\hline $\mathrm{T} 4-\mathrm{P}_{40} \mathrm{~K}_{40}$ & 10.3 & 1.5 & 4.4 & 17.7 & 3244 \\
\hline $\mathrm{T} 5-\mathrm{N}_{120} \mathrm{~K}_{40}$ & 9.2 & 1.7 & 11.4 & 9.6 & 3371 \\
\hline $\mathrm{T} 6-\mathrm{N}_{120} \mathrm{P}_{60} \mathrm{~K}_{40}$ & 11.6 & 1.3 & 6.6 & 15.9 & 3403 \\
\hline $\mathrm{T} 7-\mathrm{N}_{120} \mathrm{P}_{40} \mathrm{~K}_{40}+\mathrm{Znf}$ & 13.5 & 1.6 & 10.1 & 22.9 & 3246 \\
\hline $\mathrm{T} 8-\mathrm{N}_{120} \mathrm{P}_{40} \mathrm{~K}_{40}+\mathrm{FYM}$ & 11.9 & 1.4 & 7.2 & 14.0 & 3229 \\
\hline $\mathrm{T} 9-\mathrm{N}_{120} \mathrm{P}_{40} \mathrm{~K}_{40}+\mathrm{Znf}+\mathrm{FYM}$ & 12.8 & 1.3 & 7.6 & 17.6 & 3757 \\
\hline $\mathrm{T} 10-\mathrm{N}_{180} \mathrm{P}_{80}+\mathrm{Znf}$ & 12.4 & 1.0 & 12.5 & 18.1 & 3227 \\
\hline $\mathrm{T} 11-\mathrm{N}_{180} \mathrm{P}_{80} \mathrm{~K}_{40}+\mathrm{Znf}+\mathrm{FYM}$ & 11.5 & 1.2 & 5.2 & 16.2 & 3560 \\
\hline $\mathrm{T} 12-\mathrm{N}_{150} \mathrm{P}_{40} \mathrm{~K}_{40}$ & 7.3 & 1.0 & 5.4 & 16.9 & 3667 \\
\hline $\mathrm{T} 13-\mathrm{N}_{180} \mathrm{P}_{80} \mathrm{~K}_{40}+\mathrm{Znf}$ & 13.8 & 1.7 & 8.8 & 16.8 & 3484 \\
\hline T14 $-\mathrm{N}_{120} \mathrm{P}_{40} \mathrm{~K}_{40}(\mathrm{DAP})$ & 10.4 & 1.0 & 5.1 & 17.0 & 3442 \\
\hline $\mathrm{S} . \mathrm{Em}$. & 0.9 & 0.2 & 0.9 & 0.8 & 87 \\
\hline C.D. $(\mathrm{p}=0.05)$ & 2.6 & $\mathrm{NS}$ & 2.6 & 2.4 & 252 \\
\hline
\end{tabular}

Table.2 Effect of different treatments on concentration $\left(\mathrm{mg} \mathrm{kg}^{-1}\right)$ of micronutrient cations and phytic acid in wheat (cv. UP2565) grains

\begin{tabular}{|c|c|c|c|c|c|}
\hline Treatments & Zn & Cu & Fe & Mn & Phytic acid \\
\hline T1 -Control & 25.5 & 6.0 & 24.1 & 10.5 & 13640 \\
\hline $\mathrm{T} 2-\mathrm{N}_{120}$ & 33.2 & 6.5 & 28.1 & 11.7 & 13036 \\
\hline $\mathrm{T} 3-\mathrm{N}_{120} \mathrm{P}_{40}$ & 30.4 & 4.8 & 28.5 & 9.9 & 13398 \\
\hline $\mathrm{T} 4-\mathrm{P}_{40} \mathrm{~K}_{40}$ & 25.8 & 4.2 & 23.2 & 13.4 & 13423 \\
\hline $\mathrm{T} 5-\mathrm{N}_{120} \mathrm{~K}_{40}$ & 30.7 & 5.1 & 23.4 & 10.6 & 13696 \\
\hline $\mathrm{T} 6-\mathrm{N}_{120} \mathrm{P}_{60} \mathrm{~K}_{40}$ & 33.0 & 6.3 & 26.1 & 9.5 & 13276 \\
\hline $\mathrm{T} 7-\mathrm{N}_{120} \mathrm{P}_{40} \mathrm{~K}_{40}+\mathrm{Znf}$ & 24.7 & 5.1 & 20.1 & 8.8 & 13434 \\
\hline $\mathrm{T} 8-\mathrm{N}_{120} \mathrm{P}_{40} \mathrm{~K}_{40}+\mathrm{FYM}$ & 28.2 & 6.2 & 26.8 & 15.6 & 13904 \\
\hline $\mathrm{T} 9-\mathrm{N}_{120} \mathrm{P}_{40} \mathrm{~K}_{40}+\mathrm{Znf}+\mathrm{FYM}$ & 26.3 & 4.8 & 25.5 & 9.8 & 13486 \\
\hline $\mathrm{T} 10-\mathrm{N}_{180} \mathrm{P}_{80}+\mathrm{Znf}$ & 34.5 & 6.2 & 21.8 & 9.0 & 13792 \\
\hline $\mathrm{T} 11-\mathrm{N}_{180} \mathrm{P}_{80} \mathrm{~K}_{40}+\mathrm{Znf}+\mathrm{FYM}$ & 30.2 & 5.4 & 27.4 & 9.5 & 13553 \\
\hline $\mathrm{T} 12-\mathrm{N}_{150} \mathrm{P}_{40} \mathrm{~K}_{40}$ & 32.8 & 6.0 & 28.2 & 12.9 & 13986 \\
\hline $\mathrm{T} 13-\mathrm{N}_{180} \mathrm{P}_{80} \mathrm{~K}_{40}+\mathrm{Znf}$ & 35.8 & 6.4 & 27.1 & 10.6 & 13659 \\
\hline $\mathrm{T} 14-\mathrm{N}_{120} \mathrm{P}_{40} \mathrm{~K}_{40}(\mathrm{DAP})$ & 26.4 & 5.1 & 25.9 & 13.8 & 13491 \\
\hline $\mathrm{S} . \mathrm{Em}$. & 1.4 & 0.7 & 3.7 & 1 & 88 \\
\hline C.D. $(\mathrm{p}=0.05)$ & 4.1 & $\mathrm{NS}$ & $\mathrm{NS}$ & 2.8 & 257 \\
\hline & & & & & \\
\hline
\end{tabular}


Fig.1 Effect of different long term treatments on grain yield of rice (cv. PD 4) crop. The vertical bars over histograms represent C.D values at $p \leq 0.05$.

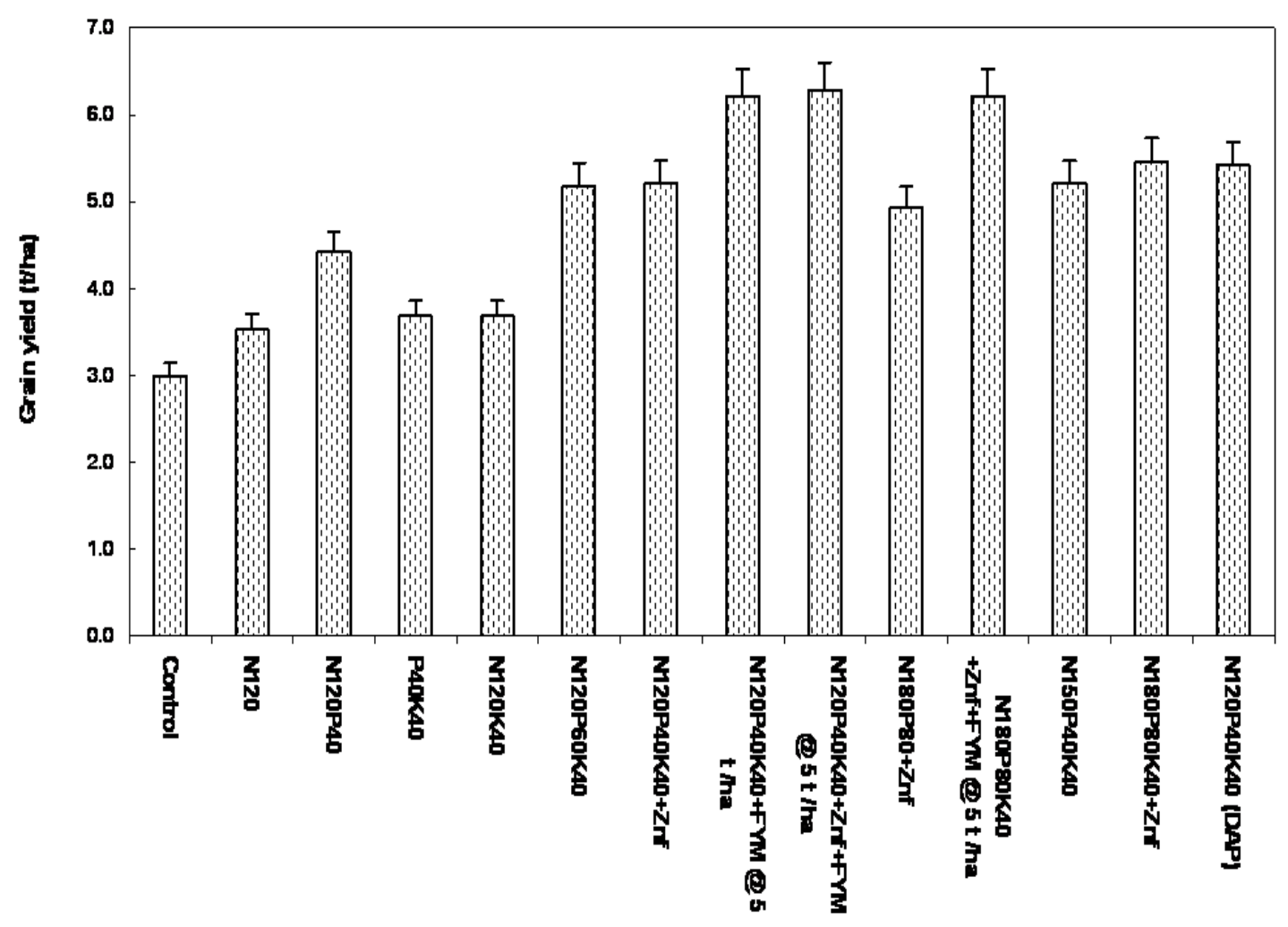

Fig.2 Effect of different long term treatments on grain yield of wheat crop. The vertical bars over histograms represent C.D values at $\mathrm{p} \leq 0.05$.

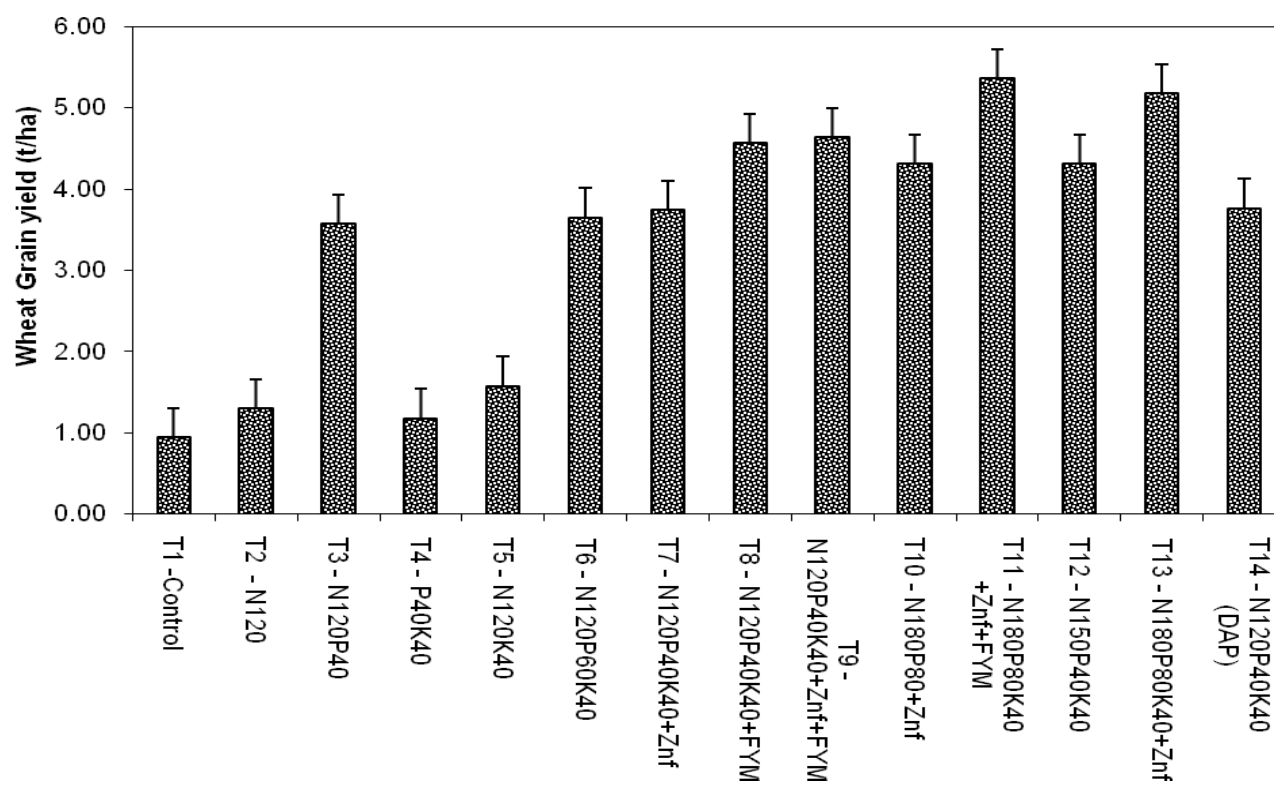


Micronutrient cations and phytic acid in wheat grains

As regards the concentration of micronutrient cations in wheat grains, the application of $\mathrm{T} 2$

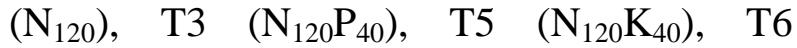
$\left(\mathrm{N}_{120} \mathrm{P}_{60} \mathrm{~K}_{40}\right), \quad \mathrm{T} 10 \quad\left(\mathrm{~N}_{180} \mathrm{P}_{80}+\mathrm{Znf}\right), \quad \mathrm{T} 11$ $\left(\mathrm{N}_{180} \mathrm{P}_{80} \mathrm{~K}_{40}+\mathrm{Znf}+\mathrm{FYM}\right), \quad \mathrm{T} 12 \quad\left(\mathrm{~N}_{150} \mathrm{P}_{40} \mathrm{~K}_{40}\right)$ and T13 $\left(\mathrm{N}_{180} \mathrm{P}_{80} \mathrm{~K}_{40}+\mathrm{Znf}\right)$ increased in $\mathrm{Zn}$ content of wheat grains significantly by 30.3 , $19.1,20.5,29.5,35.1,18.3,28.7$ and 40.3 percent over the control, respectively (Table 2). Niyigaba et al., (2019) also noted that foliar spray of $\mathrm{Zn}$ improved $\mathrm{Zn}$ concentration in winter wheat grains. Like dehusked rice grains, a comparison of $\mathrm{Zn}$ content in wheat grains raised under T14 $\left(\mathrm{N}_{120} \mathrm{P}_{60} \mathrm{~K}_{40}\right.$, supplied through DAP) with that of control revealed that continuous use of DAP did not help in raising the content of $\mathrm{Zn}$ in wheat grains. The contents of $\mathrm{Cu}$ and $\mathrm{Fe}$ in wheat grains were not significantly influenced by different treatments. Application of $\mathrm{T} 4\left(\mathrm{P}_{40} \mathrm{~K}_{40}\right), \mathrm{T} 8$ $\left(\mathrm{N}_{120} \mathrm{P}_{40} \mathrm{~K}_{40}+\mathrm{FYM} @ 5\right.$ t/ha) and $\mathrm{T} 14$ $\left[\mathrm{N}_{120} \mathrm{P}_{40} \mathrm{~K}_{40}\right.$ (DAP)] increased the content of $\mathrm{Mn}$ in wheat grains significantly by 27.3, 48.9 and 31.6 percent over the control, respectively.

The content of phytic acid in grains of wheat was significantly influenced by the treatments. Application of T8 $\left(\mathrm{N}_{120} \mathrm{P}_{40} \mathrm{~K}_{40}+\mathrm{FYM}\right)$ and $\mathrm{T} 12$ $\left(\mathrm{N}_{150} \mathrm{P}_{40} \mathrm{~K}_{40}\right)$ increased the content of phytic acid in the grains by 1.9 and 2.5 percent over the control, respectively while application of T2 $\left(\mathrm{N}_{120}\right)$ and T6 $\left(\mathrm{N}_{120} \mathrm{P}_{60} \mathrm{~K}_{40}\right)$ brought a significant decrease of 4.4 and 2.7 per cent in the content of phytic acid in comparison to control, respectively.

In general, wheat grains appeared to be relatively richer in micronutrient cations as compared to dehusked rice grains possibly because in cereals the micronutrients are accumulated in the aleuron layer and the process of dehusking and polishing removes these nutrients. A comparison of phytic acid concentrations in dehusked rice grains and wheat grains also revealed that dehusked rice grains had more than two folds higher concentration of phytic acid; an anti-nutrient factor than in wheat grains, therefore, the extent of reduction in the bioavailability of $\mathrm{Zn}$ and $\mathrm{Fe}$ in dehusked rice grains would be much higher than the case in wheat grains.

Thus, fertilizer application practices have an important bearing on the status of micronutrient cations as well as on the concentration of phytic acid in cereal grains. Long-term use of di-ammonium phosphate as a source of $\mathrm{P}$ fertilizer may cause reduced concentrations of $\mathrm{Zn}$ in dehusked rice and wheat grains and therefore, the use of single superphosphate as $\mathrm{P}$ fertilizer source has to be promoted among the farmers. In order to ensure relatively higher concentrations of $\mathrm{Zn}$ and $\mathrm{Fe}$ in cereals, the liberal foliar application of $\mathrm{Zn}$ in cereals must be promoted among the farmers. The consumption of wheat grains as a staple food offers an advantage over the consumption of dehusked rice.

\section{References}

Black, R.E., Lindsay, H.A., Bhutta, Z.A., Caulfield, L.E., De Onnis M., Ezzati, M., Mathers, C., Rivera, J. 2008. Maternal and child under-nutrition: global and regional exposures and health consequences. Lancet. 371, 243-60.

Benton, D. 2008. Micronutrient status, cognition and behavioral problems in childhood. European Journal of Nutrition. 47, 38-50.

Cakmak, I., Kalayci, M., Kaya, Y., Torun, A.A., Aydin, N., Wang, Y., Arisoy, Z., Erdem, H., Yazici, A., Gokmen, O., Ozturk, L., Horst, W.J. 2010. Biofortification and localization of zinc in wheat grain. Journal of 
Agriculture and Food Chemistry. 58:9092-9102.

Davidsson, L., Almgren, A., Sandström, B. and Hurrell, R.F. (1995) Zinc absorption in adult humans: The effect of iron fortification. British Journal of Nutrition. 74:417-425.

Gianquinto, G., Abu-Rayyan, A., Tola, L.D., Piccotino, D., Pezzarossa, B. 2000. Interaction effects of phosphorus and zinc on photosynthesis, growth and yield of dwarf bean grown in two environments. Plant and Soil. 220, 219-228.

Graham, R.D. 2008. Micronutrient deficiencies in crops and their global significance. In: B.

J. Alloway (ed). Micronutrient deficiencies in global crop production. Springer, New York, pp: 41-61.

Harland B.F., Oberleas D. (1977): A simple and rapid method for phytate determination. Cereal Chemistry, 54: 827.

Lott, J.N.A. 1984. Accumulation of seed reserves of phosphorus and other minerals. In: D.R.

Murray, (ed). Seed Physiology, Academic Press, New York, pp: 139-166.

Niyigaba,E., Twizerimana, A., Mugenzi, I., Ngnadong, W.A., Ye, Y. P., Wu, B.M. and Hai, J. B. (2019). Winter Wheat
Grain Quality, Zinc and Iron Concentration Affected by a Combined Foliar Spray of Zinc and Iron Fertilizers. Agronomy 9: 250. doi:10.3390/agronomy 9050250

Rhou, J.R., Erdman, J.V. 1995. Phytic acid in health and disease. CRC Critical Reviews in Food Science and Nutrition. 35, 495-508.

Srivastava, P.C. and Gangwar, M.S. (1990). Critical limits of zinc in mollisols and rice plant parts for predicting response of rice to zinc application. Oryza. 27: 291-295.

Srivastava, P.C.; Bhatt, M.; Pachauri, S.P. and Tyagi, A.K. (2013). Effect of different zinc application methods on apparent utilization efficiency of zinc and phosphorus fertilizers under Basmati rice-wheat rotation. Archives of Agronomy \& Soil Science. 60: 33-48.

Snedecor GW, Cochran WG (1967) Statistical Methods, Sixth Edition, The Iowa state university Press, Ames.

Volkmar, K.M. and Bremer, E. 1998. Effect of seed inoculation with a strain of Pseudomonas fluorescens on root growth and activity of wheat in wellwatered and drought-stressed glassfronted rhizotrons. Canadian Journal of Plant Science. 78, 545-551.

\section{How to cite this article:}

Pachauri, S. P., P. C. Srivastava, Deepa Rawat, B. Mathpal, S. C. Sankhyadhar, P. C. Pandey and Shukla, A. K. 2021. Effect of Fertilizer Management Practices on Grain Yields, Concentrations of Micronutrient Cations and Phytic Acid in Rice and Wheat Grains under a Long Term Fertility Trial. Int.J.Curr.Microbiol.App.Sci. 10(02): 1718-1724. doi: https://doi.org/10.20546/ijcmas.2021.1002.202 